UDC 341:339.727.22

CERIF: S144, S186

\author{
Mirko Vasiljević, $\mathrm{PhD}^{*}$ \\ Marko Jovanović, $\mathrm{PhD}^{* *}$
}

\title{
NECESSITY AS A GROUND FOR PRECLUDING WRONGFULNESS IN INTERNATIONAL INVESTMENT LAW
}

\begin{abstract}
The issue of necessity as a ground for precluding wrongfulness has received close attention over the last two decades both in case law and in scholarly writings. Arbitrations conducted against Argentina for breaches of bilateral investment treaty obligations committed while fighting against economic crisis revived the old controversies related to the concept of necessity in general public international law, but also brought up some new dilemmas. This paper analyses the use of necessity in international investment law in light of what the authors suggest to be the legal purpose of this concept, points to and discusses the divergences in case law with respect to some of the elements of the defence based on necessity and offers the solutions susceptible to lead to a more harmonious understanding of necessity in international investment law.
\end{abstract}

Key words: Necessity. - International Investment Law. - Ecological Emergency. - Economic Emergency. - Bilateral Investment Treaties.

\section{INTRODUCTION}

The rules of general public international law have played an important role in shaping the modern law of investment protection. ${ }^{1}$ Even

* Professor, University of Belgrade Faculty of Law, vaske@ius.bg.ac.rs.

** Assistant Professor, University of Belgrade Faculty of Law, marko.jovanovic@, ius.bg.ac.rs.

1 K. J. Vandevelde, “A Brief History of International Investment Agreements”, University of California Davis Journal of International Law and Policy 1/2005, 157-194; 
though today, at the time when the process of "treatification"2 of international investment law has well advanced, one might be tempted to conclude that investment law has grown into an autonomous and specialized set of rules fully emancipated from general international law, the bonds between the two normative systems are still not entirely broken. Despite the existence of a dense web of bilateral and multilateral investment treaties and provisions on investment protection in municipal law, investment arbitration tribunals have not ceased to rely on general rules of international law. ${ }^{3}$ One of the areas of investment law where the rules of general international law still find their recurrent applicability is the area of exclusion of the host State responsibility for protection of foreign investments on its territory. There are several types of circumstances which preclude wrongfulness in international law: consent, compliance with peremptory norms, self-defence, countermeasures, force majeure, distress and necessity. ${ }^{4}$ Two of these grounds are the most likely to be relied upon by States in investment arbitrations as a defence against claims for violation of investors' rights: force majeure and necessity. ${ }^{5}$ This paper will focus on the latter.

Unlike force majeure, in case of which a State justifiably disrespects its international obligation due to an unpredictable, irresistible and external factor, necessity refers to a situation where a State has made a conscious comparison of values in conflict and deliberately decided to sacrifice one in order to protect another. It is thus precisely due to this subjective element - the assessment of relative importance of the con-

Peter Muchlinski, "Policy Issues", The Oxford Handbook of International Investment Law (eds. Peter Muchlinski, Federico Ortino, Christoph Schreuer), Oxford University Press, Oxford 2008, 16-19; R. Dolzer, C. Schreuer, Principles of International Investment Law, Oxford University Press, Oxford 2012 2 1-19.

2 For an overview of ever-increasing role of international treaties as sources of investment law see: R. Echandi, "Bilateral Investment Treaties and Investment Provisions in Regional Trade Agreements: Recent Developments in Investment Rulemaking", Arbitration under International Investment Agreements: A Guide to Key Issues (ed. Katia Yannaca-Small), Oxford University Press, Oxford 2010, 3-6.

3 More on this point see P. Dumberry, "A Few Observations on the Remaining Fundamental Importance of Customary Rules in the Age of Treatification of International Investment Law", ASA Bulletin 1/2016, 41-61.

4 See Arts. 20-26 of Articles on Responsibility of States for Internationally Wrongful Acts 2001 (hereinafter: ARSIWA).

5 A. K. Bjorklund, "Emergency Exceptions: State of Necessity and Force Majeure", The Oxford Handbook of International Investment Law (eds. Peter Muchlinski, Federico Ortino, Christoph Schreuer), Oxford University Press, Oxford 2008, 461. Cf. Alexis Martinez, "Invoking State Defenses in Investment Treaty Arbitration", The Backlash Against Investment Arbitration (eds. Michael Waibel et al.), Kluwer Law International 2010, 316; R. Doak Bishop, J. Crawford, W. Michael Reisman, Foreign Investment Disputes: Cases, Materials and Commentary, Kluwer Law International 2014², 897. 
flicting values at stake - that necessity is often considered to be a highly controversial ground of defence in international law. ${ }^{6}$

What is more, the recent investment arbitrations against Argentina ${ }^{7}$ have added new aspects to the already controversial character of the defence based on necessity in international investment law. Namely, the controversies which follow the defence based on necessity in investment arbitration are not only due to the complexity of the necessity exception itself, but also to the fact that State defences based on customary law grounds can sometimes be confused with the so-called "non-precluded measures clauses" ${ }^{8}$. Even though both necessity and non-precluded measures eventually lead to the same result - the exclusion of State liability, the conditions for successfully invoking necessity need not correspond to the conditions that must be fulfilled for resorting to non-precluded measures. $^{9}$ Therefore, investment tribunals ought to pay close attention to the set of conditions they examine when deciding on each of the respective grounds of defence, which, as we will show further on, did not always occur in practice.

In light of the aforementioned controversies, the aim of this paper will be to present and analyse the specificities regarding the use of the defence based on necessity in international investment law. In order to achieve this goal, we will start off by explaining the basics of the concept of necessity in general public international law (2.) and then turn to its particularities in international investment law (3.).

6 Case Concerning the Difference between New Zealand and France (Rainbow Warrior), 30 April 1990, Reports of International Arbitral Awards vol. XX, 254; M. Shaw, International Law, Cambridge University Press, Cambridge 20086, 798.

7 Since the outbreak of the Argentinean economic crisis in the end of the $20^{\text {th }}$ and the beginning of the $21^{\text {st }}$ century, more than 40 investment claims were lodged against it before the International Centre for Settlement of Investment Disputes (ICSID). A detailed and updated list of cases is available at: https://icsid.worldbank.org/apps/ICSIDWEB/ cases/Pages/AdvancedSearch.aspx? rntly=ST4, last visited 1 October 2016. However, this is not the full list of cases, since some disputes were resolved under other procedural mechanisms, such as ad hoc arbitrations pursuant to the UNCITRAL Rules.

8 "Non-precluded measures clauses" are provisions contained in an international treaty which stipulate that nothing in that treaty shall preclude a State party to take measures that are necessary to protect a certain interest. More on these clauses in bilateral investment treaties see: W. Burke-White, A. von Staden, "Investment Protection in Extraordinary Times: The Interpretation and Application of Non-Precluded Measures Provisions in Bilateral Investment Treaties", Virginia Journal of International Law 2/2008, 307-410.

9 On the differences between the two grounds of defense in the context of the Argentinean economic crisis see: T. Gazzini, "Foreign Investment and Measures Adopted on Ground of Necessity: Towards a Common Understanding", Transnational Dispute Management 1/2010, 1-28; P. Tomka, "Defenses Based on Necessity Under Customary International Law and on Emergency Clauses in Bilateral Investment Treaties", Building International Investment Law: The First 50 Years of ICSID (eds. Meg Kinnear et al.), Kluwer Law International 2015, 477-494. 


\section{BASIC CHARACTERISTICS OF THE CONCEPT OF NECESSITY IN GENERAL PUBLIC INTERNATIONAL LAW}

The customary concept of necessity is codified $^{10}$ in the International Law Commission's Articles on Responsibility of States for Internationally Wrongful Acts of 2001 (hereinafter: ARSIWA). Even though the current wording is considered to be a somewhat enlarged version of the necessity provision which existed in the 1996 draft, ${ }^{11}$ ARSIWA nevertheless contain a very strict and exceptional concept of necessity. The strictness of the concept is reflected in the requirement that all conditions for the application of necessity must be cumulatively met for this defence to be successfully invoked. ${ }^{12}$ The exceptional character of the necessity defence is emphasized by the negative wording of Article 25 ARSIWA necessity may not be invoked unless all the conditions prescribed are met. $^{13}$

Namely, Article 25 of ARSIWA reads:

"Necessity may not be invoked by a State as a ground for precluding wrongfulness of an act not in conformity with an international obligation of that State unless the act:

(a) Is the only way for the State to safeguard an essential interest against a grave and imminent peril; and

10 Even though the International Court of Justice held, though without further explanation, that Art. 25 ARSIWA reflects customary international law on necessity (see Case Concerning the Gabčikovo-Nagymaros Project (Hungary/Slovakia), Judgment of 25 September 1997, ICJ Reports 1997, para. 52; Legal Consequences of the Construction of a Wall in the Occupied Palestinian Territory, Advisory Opinion of 9 July 2004, ICJ Reports 2004, para. 140), some authors argue that the aforementioned provision might represent not only the codification but also the progressive development of international law (see R. Boed, "State of Necessity as a Justification for Internationally Wrongful Conduct", Yale Human Rights and Development Journal 1/2000, 45; D. Caron, "The ILC Articles on State Responsibility: The Paradoxical Relationship between Form and Authority", American Journal of International Law 4/2002, 874; I. Brownlie, Principles of Public International Law, Oxford University Press, Oxford 20087, 466; R. Sloane, "On the Use and Abuse of Necessity in the Law of State Responsibility", The American Journal of International Law 4/2012, 450). Bearing in mind the topic and purpose of this paper, we will not take position on this question and we will content ourselves with merely noting various opinions on the issue.

11 S. Heathcote, "Circumstances Precluding Wrongfulness in the ILC Articles on State Responsibility: Necessity", The Law of International Responsibility (eds. James Crawford, Alain Pellet, Simon Olleson), Oxford University Press, Oxford 2010, 495.

12 M. Agius, "The Invocation of Necessity in International Law", Netherlands International Law Review 2/2009, 99.

13 International Law Commission, "Draft Articles on Responsibility of States for Internationally Wrongful Acts, with Commentaries" (hereinafter: Commentary), Yearbook of International Law Commission vol. II, 2001, 83, para. 14. 
(b) Does not seriously impair an essential interest of the State or States towards which the obligation exists, or of the international community as a whole.

In any case, necessity may not be invoked by a State as a ground for precluding wrongfulness if:

(a) The international obligation in question excludes the possibility of invoking necessity; or

(b) The State has contributed to the situation of necessity."

As its structure shows, Art. 25 ARSIWA contains two sets of conditions for the application of necessity: the conditions related to the balancing of conflicting interests at stake and the conditions of absolute preclusion of the possibility to resort to necessity defence. ${ }^{14}$ The first, "positive" set of conditions encompasses five elements: (1) the existence of an essential interest, (2) a threat to such interest by a grave and imminent peril, (3) the lesser value of the interest sacrificed compared to the interest safeguarded, (4) the requirement that the act taken in necessity is the only means to safeguard the essential interest, and (5) the requirement that the adequate balance of interests exists on a bilateral or multilateral level, or in relation to the international community as a whole. The second, "preclusive" set of conditions requires the absence of two elements: (1) unsuitableness of the international obligation to be disrespected in necessity and (2) the contribution of the State to the situation of necessity.

The involvement of an essential interest appears to be the keystone of the necessity concept as laid down in Art. 25 ARSIWA. This element should be considered both on the side of the State acting in necessity and on the side of the State or the States injured, and its importance is twofold. On the one hand, the existence of the essential interest provides legitimacy to the act taken in necessity since the breach of an international obligation may be justified only if committed in view of protecting an essential interest of the breaching State. ${ }^{15}$ Historically, States have relied upon the need to preserve an essential interest in cases where there was a danger of extermination of certain animal species ${ }^{16}$ or the threat of a biological hazard ${ }^{17}$. On the other hand, the essential interest of the State or

14 For such taxonomy of conditions see S. Heathcote, 496. Cf. M. Agius, $102-111$.

15 Art. 25(1)(a) ARSIWA.

16 E.g. Russian Fur Seals Controversy (1893), cited in Commentary of Draft Articles on Responsibility of States for Internationally Wrongful Acts, Yearbook of the International Law Commission vol. II(2), 2001, 81.

17 E.g. The Torrey Canyon Incident (1967), cited in Commentary of Draft Articles on Responsibility of States for Internationally Wrongful Acts, Yearbook of the International Law Commission vol. II(2), 2001, 82. 
the States injured by the breach constitutes a boundary to the act taken in necessity, since the breach of an international obligation committed in necessity may not seriously impair an essential interest of the State or States towards which the obligation exists, or of the international community as a whole. ${ }^{18}$

Nevertheless, the very definition of the term 'essential interest' is left open in the text of ARSIWA. This was done intentionally, ${ }^{19}$ since it was believed that the essential character of an interest invoked should be assessed in light of all circumstances of each particular case ${ }^{20}$. By way of example only, it was stated that the essential interest may take a form of a State's "(...) political or economic survival, the continued functioning of its essential services, the maintenance of internal peace, the survival of a sector of its population, the preservation of the environment of its territory or a part thereof, etc." ${ }^{21}$ It seems, however, that this approach of the International Law Commission makes it possible to argue that Art. 25 ARSIWA objectivises to a certain extent the concept of essential interest. Namely, it is our understanding that, precisely by stating that the essential character of the interest safeguarded should be established in each particular case, the International Law Commission actually suggests that the assessment of the essential character of an interest is suitable to be subjected to review - the subjective assessment of the State acting in necessity as to the essential character of the interest that it was safeguarding does not suffice. ${ }^{22}$ This will prove to be particularly important for the use of necessity in investment disputes.

Not only do ARSIWA leave the notion of essential interest open, but they also contain no guidelines as to how the reference to grave and imminent peril should be interpreted. It was therefore left to commentaries and case law to define the said notion. Accordingly, with respect to the element of graveness of the peril, it was submitted that the peril " (...) does not need to take the form of a threat to the life of individuals whose conduct is attributed to the State, but [that it can represent] a grave danger to the existence of the State itself, its political or economic survival, the continued functioning of its essential services, the maintenance of inter-

18 Art. 25(1)(b) ARSIWA.

19 J. Crawford, "Second Report on State Responsibility - Document A/CN.4/498/ ADD.1-4", 1999, para. 283, available at: http://legal.un.org/ilc/documentation/english/a_ cn4_498.pdf, last visited 1 October 2016.

20 International Law Commission, "Report on State Responsibility - Document A/35/10", Yearbook of the International Law Commission vol. II(2), 1980, 49, para. 32.

21 R. Ago, "Addendum to the Eighth Report on State Responsibility - Document A/CN.4/318/ADD.5-7", Yearbook of the International Law Commission vol. II(1), 1980, 14, para. 2.

22 For a discussion on this point see A. Bjorklund, 503-505; S. Heathcote, 496. 
nal peace, the survival of a sector of its population, the preservation of the environment of its territory or a part thereof, etc."23. As far as the element of imminence of the peril is concerned, the International Court of Justice (hereinafter: the ICJ or the Court) stated that the "[i]mminence is synonymous with 'immediacy' or 'proximity' and goes far beyond the concept of "possibility" 24 . This is very important for understanding the boundaries of the concept of necessity. Namely, even though the word 'peril' implies the element of risk as opposed to 'damage' where the detriment has already materialized, ${ }^{25}$ the requirement of its imminence prevent the necessity to serve as a precautionary principle but rather limits it to a "(...) preventative mechanism [for] managing crises [already occurred] which, if not averted, will lead to grave harm"26.

A particularly delicate element of the concept of necessity is the requirement that the disrespect of an international obligation represents "the only way" for the State to preserve its essential interest. It is understood that the reliance on necessity is excluded where "(...) there are other (otherwise lawful) means available, even if they may be more costly or less convenient" 27 . Due to such restrictive understanding, this requirement significantly narrows down the possibility of invoking necessity. Even though some authors consider that the role of this element is decreasing over time in international law, ${ }^{28}$ it should be noted that the landmark decisions of the ICJ in the matter of necessity still find this requirement vital and important. ${ }^{29}$

Despite its exceptional character, the defence based on necessity plays an important role in international law. It serves, as stated in doctrine, "to avoid an overly rigid application of the law in circumstances where there are conflicting values" 30 : one of a fundamental character (which needs to be safeguarded) and the other of a comparatively lesser importance (which is to be sacrificed). In other words, the concept of necessity is meant to be a "(...) safety valve [used] to relieve the inevitably untoward consequences of a concern for adhering at all costs to the

23 R. Ago, "Addendum to the Eighth Report on State Responsibility - Document A/CN.4/318/ADD.5-7", Yearbook of the International Law Commission vol. II(1), 1980, 14.

24 Gabčikovo-Nagymaros, para. 54.

25 Ibidem.

26 S. Heathcote, 497.

27 Commentary, 83, para. 14.

28 M. Agius, 105.

29 See Gabčíkovo-Nagymaros, para. 58; Construction of Wall, para. 140.

30 S. Heathcote, "Circumstances Precluding Wrongfulness in the ILC Articles on State Responsibility: Necessity", The Law of International Responsibility (eds. James Crawford, Alain Pellet, Simon Olleson), Oxford University Press, Oxford 2010, 491. 
letter of law"31. Accordingly, the concept of necessity might be viewed as a legal tool which enables fair and distribution of detriment arising out of the situation where there is a grave and imminent peril to the occurrence of which the State did not contribute and which threatens its essential interests. ${ }^{32}$ It is precisely in light of that purpose of necessity that we will assess the use of this concept in international investment law.

\section{USE OF NECESSITY IN INTERNATIONAL INVESTMENT LAW}

At the turn of the $21^{\text {st }}$ century the issue of necessity started becoming relevant for a specific type of international disputes - disputes related to the protection of foreign investments. There were two emblematic situations in which States argued the existence of an essential interest: threats to ecological safety (3.1) and economic stability (3.2). Other situations that would give rise to necessity have not yet been recorded in case law.

\subsection{Ecological safety as a ground for invoking necessity}

Ecological safety as the essential interest of a State was in focus of the Gabčikovo-Nagymaros case before the ICJ. This dispute arose after Hungary decided to unilaterally suspend and some time later abandon certain obligations under a treaty with Slovakia concerning joint works on a part of the River Danube, which forms the natural border between the two countries. Even though this was not a "classical" investment dispute in the sense that it opposed an investor to a host State, the case nevertheless did revolve around a project that, on the basis of its duration, risks associated to its performance, magnitude and importance may qualify as an investment jointly performed by two States. In the proceedings before the ICJ Hungary relied on the "state of ecological necessity" in order to justify its withdrawal from the project. Namely, Hungary argued that, if the project were to be entirely carried out as set by the HungarySlovakia treaty, this could lead to such changes in the environment that would be likely to result in the artificial floods and changes of groundwater level, significant drop of quality of water in certain parts of the country and consequently, to the extinction of the fluvial flora and fauna as well as of certain species living in alluvial planes. ${ }^{33}$

31 R. Ago, "Addendum to the Eighth Report on State Responsibility - Document A/CN.4/318/ADD.5-7", Yearbook of the International Law Commission vol. II(1), 1980, 51, para. 80 .

32 For a detailed economic analysis of necessity see A. Sykes, "Economic 'Necessity' in International Law", American Journal of International Law 2/2015, 296-323. Although we do not necessarily agree with all the conclusions presented by this author, we draw attention to the complexity and perceptiveness of his analysis.

33 Gabčíkovo-Nagymaros, para. 40. 
As it is expressly stated in the judgment, the ICJ had "no difficulty" finding that the protection of environment as argued by Hungary indeed presented an essential interest within the doctrine of necessity, ${ }^{34}$ and invoked an earlier advisory opinion issued by the Court which emphasized the significance of a healthy environment for human beings, "including generations unborn" 35 . Therefore, the Court's upholding of the need for preservation of ecological safety may indeed constitute an essential interest of a State and give rise to breaches of the investment-related international obligations committed in necessity. However, what appeared to be more difficult for Hungary to prove in the case at hand were other elements of the defence based on necessity. Namely, the Court found that Hungarian essential interests were not exposed to grave and imminent peril $^{36}$ and that Hungary could have resorted to means other than the breach of the treaty with Slovakia in order to effectively address its environmental concerns (though it failed to specify what these means may have been in concreto). ${ }^{37}$

Even though the Gabčikovo-Nagymaros judgment represents one of the landmark decisions in the modern general international law of necessity, its helpfulness for clarifying the specificities of the operation of necessity in international investment law seems somewhat doubtful. We acknowledge that the judgment is fundamentally important for it confirms that ecological safety could generally constitute an essential interest of a State susceptible to be safeguarded in necessity. Furthermore, the Court pointed to the importance of properly proving the requirement of "grave and imminent peril" by declaring that this condition must be substantiated and proven with sufficient certainty. This point was subsequently developed at a general plan by Prof. James Crawford in his Second Report on State Responsibility, where he submitted that "(...) the peril [should be] established on the basis of the evidence reasonably available at the time" ${ }^{38}$. Nevertheless, it should be noted that the Gabcíkovo-Nagymaros dispute did not arise from the breach of a bilateral investment treaty (hereinafter: BIT), which is the most common legal basis of international investment disputes. Therefore, the findings of the ICJ on specific elements of the availability of the defence based on necessity in cases of threat to ecological safety (especially the one relating to the "only way" requirement) do not seem particularly insightful for predicting the likely outcomes of relying on this defence in a BIT-arbitration.

\footnotetext{
34 Ibid., para. 53.

35 Legality of Threat or Use of Nuclear Weapons, Advisory Opinion of 8 July 1996, ICJ Reports 1996, para. 29, cited in: Gabčíkovo-Nagymaros, para. 53.

36 Gabčikovo-Nagymaros, paras. 42-44.

37 Ibid., paras. 44-45.

38 J. Crawford, para. 291.
} 


\subsection{Economic stability as a ground for invoking necessity}

The preservation of economic stability as an essential interest of a State was relied upon by Argentina in several investment arbitrations led against it following the economic and fiscal crisis that this country had faced in the late $90 \mathrm{~s} .{ }^{39}$ In an attempt to stop economic recession which led to social unrest and a series of political leadership changes, the government introduced legislation that allowed for the renegotiation of contracts with public services providers (who were mostly foreign investors), reformed the foreign currency exchange system (which brought significant losses to foreign investors) and restricted transfers out of the territory of the country. Argentina argued that the emergency measures did not constitute a breach of its obligations under BITs but even if they did, Argentina should be exempted from liability since "(...) the very existence of the Argentine State was threatened by the events that began to unfold in 2000" ${ }^{40}$ Consequently, the State was acting in an attempt to prevent economic, financial and social stability, which represented, in the eyes of Argentina, its essential interest.

Arbitrations arising out of the measures taken by Argentina in order to deal with the economic crisis received significant attention in scholarly writings ${ }^{41}$ since they highlighted many dilemmas that emerge from the application of the concept of necessity to investment protection cases. The initial question might already refer to whether the necessity could even be invoked in investment arbitrations. This problem was briefly touched upon by the tribunal in $B G$ Group, where the arbitrators first declared that the necessity exception pursuant to the rules of customary (i.e. general) international law was inoperable in the case at hand since Art. 25 ARSIWA may relate exclusively to international obligations between sovereign States, but they then nevertheless proceeded to examining whether the conditions for application of necessity exception were

39 See in particular: CMS Gas Transmission Company v Argentina, ICSID Case No. ARB/01/8; Enron Corporation and Ponderosa Assets, L.P. v Argentina, ICSID Case No. 01/3; LG\&E Energy Corporation et al. v Argentina, ICSID Case No. ARB/02/1; Sempra Energy International v. Argentina, ICSID Case No. ARB/02/16; Continental Casualty $v$ Argentina, ICSID Case No. ARB/03/9; El Paso Energy International Company v Argentina, ICSID Case No. ARB/03/15; BG Group v Argentina, ad hoc arbitration pursuant to UNCITRAL Rules; National Grid v Argentina, ad hoc arbitration pursuant to UNCITRAL Rules.

40 CMS, Award of 12 May 2005, paras. 304-305.

41 See e.g. M. Waibel, "Two Worlds of Necessity in ICSID Arbitration: CMS and LG\&E", Leiden Journal of International Law 3/2007, 637-648; J. Fouret, "CMS c/ LG\&E ou l'état de nécessité en question", Revue de l'Arbitrage 2/2007, 249-272; A. Bjorklund, 459-523; W. Burke-White, A. von Staden, 307-410; A. Martinez, 318-327; A. Reinisch, "Necessity in Investment Arbitration", Netherlands Yearbook of International Law, vol. 40, 2010, 137-158; P. Tomka, 477-494. 
satisfied and reached a negative conclusion. ${ }^{42}$ Other tribunals did not dispute the possibility of reliance on necessity in investment protection cases and the doctrine does not seem to challenge the applicability of the customary concept of necessity in the context of investment arbitration. ${ }^{43}$

What is particularly noteworthy when it comes to Argentinean arbitrations arising out of the measures taken in order to deal with economic crisis is the fact that even though all disputes arose out of the same factual background and most of them were even based on the same BIT (Argentina-USA) ${ }^{44}$, the tribunals reached sometimes diametrically different conclusions on certain aspects of necessity. On the one hand, there were tribunals which found that the defence based on necessity was justified ${ }^{45}$ while, on the other hand, there was also a significant body of decisions where the necessity was ruled out. ${ }^{46}$ This divergence is generally justified as the reflection of absence of the stare decisis principle in investment arbitration, ${ }^{47}$ but it also sheds light at certain difficulties in applying the concept of necessity in international investment law. It should be therefore unsurprising that some tribunals were creative in finding ways to avoid the discussion on the justification of the defence based on necessity. ${ }^{48}$

We will now proceed to presentation and discussion of the most important differences in approaches of the tribunals to the particular elements of necessity.

\subsubsection{Grave and imminent peril to an essential interest}

At the outset, the assessment of the essential character of the need for preservation of economic stability in practice of investment arbitration tribunals proved to be somewhat more complex than in case of ecological safety. The tribunal in $L G \& E$ found that the situation in Argentina ex-

42 See BG Group, Award of 24 December 2007, paras. 407-412.

43 In that sense: P. Tomka, 493-494.

44 This BIT was signed on November 14, 1991 and entered into force on October 20, 1994. Its text is available at: http://investmentpolicyhub.unctad.org/Download/ TreatyFile/127, last visited 1 October 2016.

45 See the awards in $L G \& E$ and Continental Casualty.

46 See the awards in CMS, Enron and National Grid.

47 J. Fouret, 250.

48 See e.g. Metalpar y Buen Aire v Argentina, ICSID Case No. ARB/03/5, Award on the Merits, 6 June 2008, paras. 208-213, where the Tribunal declared that they did not need to examine whether the necessity was justified since Claimants did not prove that their investment was adversely affected by Argentinean measures taken to fight the crisis. For a commentary of this decision see: Iñigo Iruretagoiena Agirrezabalaga, "El estado de necessidad, como causal eximente de la responsabilidad por daños a las inversiones", Revista de Arbitraje Comercial y de Inversiones 1/2009, 199-209. 
ceeded mere economic problems and business cycle fluctuations but it rather reached "catastrophic proportions" and "the highest degree of public disorder", threatening total collapse of the Government and the State, as well as Argentina's essential security interests. ${ }^{49}$ The tribunal in Continental Casualty, although discussing the issue from the standpoint of Art. XI of the Argentina-USA BIT (non-precluded measures clause), reached a similar conclusion. ${ }^{50}$ Somewhat more cautiously, the tribunal in $C M S$ admitted that the crisis was indeed severe but it also added "[A]s is many times the case in international affairs and international law, situations of this kind are not given in black and white but in many shades of grey". ${ }^{51}$ Finally, the tribunal in Enron considered that the extent of the economic crisis in Argentina was not sufficient to compromise the very existence of the Argentinean State so that, consequently, it may not have been qualified as involving an essential interest. ${ }^{52}$

Despite certain differences in nuance and tone of the aforecited decisions, it may be concluded that all four tribunals nevertheless share a common point - they all agree that, in abstracto, the preservation of economic stability may generally qualify as essential interest of a State. ${ }^{53}$ This is an important contribution because the earlier practice of necessity in general international law did not provide for an unambiguous answer to this question. ${ }^{54}$ The differences in wording stem from the fact that the tribunals often considered the requirement of essential character along with the requirements of grave and imminent peril and the non-availability of other means for overcoming the crisis, ${ }^{55}$ which are the true points around which the opinions were divided.

Even though the ICJ in the Gabcikovo-Nagymaros judgment introduced solid guidelines for assessing the graveness and imminence of a peril, the tribunals in the Argentinean cases did not seem to be willing to engage into a methodological and substantiated evaluation of the extent and immediacy of the economic crisis. Some tribunals even completely refrained from examining whether this condition was fulfilled since they had already found that other, more easily provable elements of necessity were not established, so they considered that further examination of other elements was redundant. ${ }^{56}$ The decisions in which the issue of graveness

$49 L G \& E$, Decision on Liability of 3 October 2006, paras. 231-232.

50 Continental Casualty, Award of 5 September 2008, para. 178.

51 CMS, Award of 12 May 2005, para. 320.

52 Enron, Award of 22 May 2007, para. 306.

53 In that sense: A. Bjorklund, 481.

54 J. Fouret, 259-260; M. Waibel, 641-642; A. Reinisch, 145-146.

55 In that sense, for Enron dispute, see Enron, Decision on Annulment of $30 \mathrm{Jul}$ 2010, para. 360 .

56 National Grid, Award of 3 November 2008, para. 262. 
and imminence of the peril was discussed can be divided into two groups. The first group is gathered around the CMS award, where the tribunal simply, and without any particular explanation, declared that " $[t]$ he relative effect of the crisis [does not] allow (...) for a finding in terms of preclusion of wrongfulness" ${ }^{57} .{ }^{5}$ A different conclusion was reached by the $L G \& E$ tribunal, which, somewhat surprisingly, did not use the terms "grave and imminent peril", but rather concluded that Argentina "[f]aced an extremely serious threat to its existence (...)" ${ }^{\prime 59}$. Nevertheless, the tribunal performed a very interesting three-layered analysis of the economic situation in Argentina within which it considered the social situation in Argentina, specially emphasizing the speedy deterioration of the Gross Domestic Product, increasing unemployment rate and the significant drop of the buying power, took into consideration an unstable political situation in the country and examined the content and the effect of the legislation adopted to fight the crisis. ${ }^{60}$

Apart from the astonishingly different results that the tribunals reached when qualifying the intensity and proximity of the threat to Argentinean essential interest, it is striking to see that most tribunals completely disregarded the need to establish an objective test for determining whether the threat to essential interests of the host State was indeed grave and imminent. The rare, if not the only exception was the Enron tribunal which stands the closest to guidelines formulated in the GabcíkovoNagymaros judgment. Bearing in mind that the economic crisis as a ground for invoking necessity is perfectly suitable to be objectively and even scientifically analysed, we do not see any convincing reason for deviation from the approach adopted in the Gabcíkovo-Nagymaros judgment with respect to determining the graveness and imminence of threat to an essential interest of the State in this type of cases.

\subsubsection{The "only way" requirement}

Stark differences developed around the understanding of the requirement that the measures taken in necessity needed to represent "only way" for safeguarding an essential interest. Pursuant to a more rigorous interpretation, adopted by the $C M S$ tribunal, the "only way" requirement shall not be deemed fulfilled whenever there was at least one other alternative to the measure taken by the host State. ${ }^{61}$ Therefore, it may be concluded that this tribunal subscribed to a literal interpretation of the "only

57 CMS, Award of 12 May 2005, para. 322.

58 In similar terms and equally without any elaboration: Enron, Award of 22 May 2007, para. 307; Sempra, Award of 28 September 2007, para. 349.

$59 L G \& E$, Decision on Liability of 3 October 2006, para. 257.

60 Ibid., paras. 230-237.

61 CMS, Award of 12 May 2005, para. 323. 
way" requirement as it considered that it sufficed to establish merely whether the measure taken had any alternatives, the assessment of appropriateness and soundness of a State's policy choices being outside the scope of a tribunal's task. ${ }^{62}$ A similar approach was taken by the Enron tribunal, which stated that it was not up to arbitration to assess which of the alternatives would be the most recommendable nor to substitute for the governmental determination of economic choices, but only to establish whether the choice made was indeed the only one available. ${ }^{63}$

However, this approach was criticised and rejected by the Annulment Committee, which adhered to a more flexible reading of the "only way" requirement, holding that it encompasses not just the existence of other alternatives but also the analysis of their relative effects. ${ }^{64}$ Accordingly, the Committee was not satisfied with the tribunal examining the mere availability of other alternatives. Rather, the Committee considered that the tribunal should have gone on to examine the appropriateness and feasibility of applying other available measures, having in mind the circumstances and information that were known to the State at the time of making the choice and not an ex post facto analysis of their potential effects. ${ }^{65}$

It was submitted in doctrine that, in cases of economic emergencies, it would seem justified to allow a more lenient interpretation to the "only way" requirement in order to leave a possibility for some practical application of this criterion (and consequently the entire concept of necessity), which would otherwise be very rarely available due to a high threshold that would exist had the term "only way" been given a strict literal interpretation. ${ }^{66}$ The ruling of the Enron Annulment Committee seems to be going in that direction, but the echoes of such approach yet remain to be heard.

\subsubsection{Non-contribution to necessity}

The examination of the non-contribution of the State to necessity appeared to be equally sensitive as was the case with the previously discussed criteria. The CMS tribunal, relying on the Commentary of ARSIWA, established that in order for this condition to be satisfied, there must a substantial and not merely incidental or peripheral contribution of the State. ${ }^{67}$ Due to the interactive nature of the global economy, the tribunal

62 Ibidem. In the similar vein see Sempra, Award of 28 September 2007, para. 350.

63 Enron, Award of 22 May 2007, para. 309.

64 Enron, Decision on Annulment of $30 \mathrm{Jul}$ 2010, paras. 368-378.

65 Ibid., paras. 371-372.

66 A. Reinisch, 154.

67 CMS, Award of 12 May 2005, para. 328. 
went on to declare that the factors leading to the Argentinean economic crisis were both endogenous and exogenous,${ }^{68}$ which warranted for a further inquiry as to the intensity of the State influence to the collapse of the economic system. Without any particular analysis or detailed justification, it found that "(...) the government policies and their shortcomings significantly contributed to the crisis and the emergency and while exogenous factors did fuel additional difficulties they do not exempt the Respondent from its responsibility in the matter ${ }^{\prime 69} .70$ On the contrary, the $L G \& E$ tribunal considered that it was upon claimant to prove that the host State contributed to necessity, ${ }^{71}$ while the Continental Casualty tribunal did not examine this issue under Art. 25 ARSIWA but rather under the non-precluded measures clause contained in the Argentina-US BIT and consequently, by applying a different, less stringent standard, found that Argentina was justified in relying on that provision ${ }^{72}$.

A more detailed discussion of the non-contribution requirement can be found in National Grid arbitration. The tribunal enumerated endogenous and exogenous factors which contributed to the crisis and then, relying upon the documents of the International Monetary Fund on the evaluation of this crisis, analysed the measures taken by Argentina and reached the conclusion that the State's response to the crisis only further contributed to its worsening. ${ }^{73}$

The tribunal in El Paso thoroughly discussed the issue of Argentina's contribution to the economic crisis,${ }^{74}$ but it also considered this point from the perspective of the non-precluded measures clause. This makes its analysis somewhat unsuitable for further discussion in relation to our topic. However, we find it important to stress that the tribunal decided to take an innovative approach in interpreting the non-precluded measures clause. Namely, it reaffirmed the standard established in its Decision on Jurisdiction, stating that " $[t]$ his Tribunal considers that a balanced interpretation is needed, taking into account both State sovereignty and the State's responsibility to create an adapted and revolutionary framework for the development of economic activities, and the necessity to protect foreign investment and its continuing flow" 75 .

68 Ibidem.

69 Ibid., para. 329

70 Similar conclusions were reached in: Enron, Award of 22 May 2007, paras. 311-312; Sempra, Award of 28 September 2007, paras. 353-354.

$71 L G \& E$, Decision on Liability of 3 October 2006, para. 256. For a comment on this point of the award see M. Waibel, 642.

72 Continental Casualty, Award of 5 September 2008, paras. 234-236. For a comment on this point of the award see A. Reinisch, 155.

73 National Grid, Award of 3 November 2008, paras. 258-261.

74 El Paso, Award of 31 October 2011, paras. 649-670.

75 Ibid., para. 650, referring to the Decision on Jurisdiction of 27 April 2006, para. 70. 
The issue of non-contribution shows the importance of making a clear distinction between the defences based on necessity and on emergency clauses. It should also be noted that almost all the tribunals sought to establish whether there was substantial contribution of Argentina to necessity, and not just any contribution, as it may stem from the plain reading of Art. 25(2)(b) ARSIWA. The support for such approach is found in the Commentary to ARSIWA, which states that "[c]ontribution to the situation of necessity must be sufficiently substantial and not merely incidental or peripheral" ${ }^{76}$. This was welcomed by doctrine since, due to the mixed nature of reasons leading to an economic crisis, it should be deemed appropriate to require a more substantial rather than merely any degree of contribution to necessity. ${ }^{77}$

\subsubsection{Non-impairment of interests of other States or international community and suitability of the obligation to be disrespected in necessity}

As far as non-impairment of interests of other States or international community as a whole is concerned, this element did not spark significant attention of the tribunals. They generally seem to agree that acts committed by Argentina did not endanger the interests of other States or of the international community ${ }^{78}$ What is more, they only mentioned but failed to elaborate on the relevance and role of the interests of private parties, investors or others, which might potentially have been appropriate, seeing the architecture and the purpose of BITs. Despite the objection that, had they done so, this might have constituted a departure from the language of Art. 25 ARSIWA, it may be argued that the hybrid nature of investor-State disputes justifies the need to balance the interests of the host State not only against other States but against private parties as well, in order to give fair chances to both parties in dispute to make their case as to the requirements for necessity. ${ }^{79}$

Finally, the least disputed seemed to be the requirement that the obligation in question does not exclude necessity. Most tribunals considered the existence of the "non-precluded measures" clause contained in some Argentinean BITs as a proof that the protection accorded by such BITs was, by its nature, susceptible to be suspended in extreme circum-

76 Commentary, 84, para. 20. This point was explicitly referred to in CMS, Award of 12 May 2005, para. 328.

77 A. Reinisch, 155.

$78 C M S$, Award of 12 May 2005, para. 325; $L G \& E$, Decision on Liability of 3 October 2006, para. 257; Enron, Award of 22 May 2007, para. 310; Sempra, Award of 28 September 2007, para. 352.

79 More on this point: A. Bjorklund, 487. 
stances. ${ }^{80}$ However, even the tribunals which took a different path came to the conclusion that the necessity defence would be available even absent the "non-precluded measures" provision. ${ }^{81}$

\section{CONCLUSION}

The analysis of the use of necessity as a ground for precluding wrongfulness in international investment law shows that the concept of necessity plays an important role in the system of investment protection. It seems, however, that, in order to maintain and uphold the purpose of necessity, which is, in our eyes, to enable fair and distribution of detriment arising out of the situation where there is grave and imminent peril to the occurrence of which the State did not contribute and which threatens its essential interests, some adjustments of the model developed in general international law should be made when necessity is applied in international investment law. Several conclusions may thus be suggested.

Firstly, the tribunals must pay close attention to the distinction between the defence based on necessity and the defence based on the application of the "non-precluded measures" clause. This is because the two defences do not have the same content and entail different elements. Consequently, different thresholds and tests should be applied when examining whether the conditions for invoking any of the two defences are fulfilled. While the defence based on necessity is always available, as a part of general international law, the defence based on a non-precluded measures clause may be invoked only when the applicable investment treaty provides for such an exception and in the way stipulated by the treaty in question.

Secondly, the interpretation of the "positive" set of requirements (Art. 25(1) ARSIWA) should take into consideration, to use the words of the tribunal in El Paso, the need to achieve a balance between State sovereignty and State's responsibility to create an adapted and revolutionary framework on the one hand, and the need to protect foreign investment and its continuing flow on the other. This is because any excessive strictness or lenience in interpreting the concept of necessity might compromise its very purpose - the fair distribution of detriments. Namely, an overly strict interpretation of necessity would render it virtually inoperable in the realm of investment protection. Foreign investments would thus be protected in all times and under all circumstances by an absolutely bulletproof shield of international obligations that could not be lifted even

$80 L G \& E$, Decision on Liability of 3 October 2006, para. 255; Enron, Award of 22 May 2007, para. 333-334; Sempra, Award of 28 September 2007, paras. 374-375.

81 CMS, Decision on the Annulment of 25 September 2007, paras. 133-134. 
in the extreme and exceptional cases. Consequently, all the detriment arising out the situation causing State to act in necessity would break down to all the economic operators and citizens in that State except the investors. This would be in sharp contrast with our view that financial burden caused by the circumstances inducing necessity should be distributed in a fair way between all the operators and citizens in the host State. Conversely, if necessity were to be interpreted in an excessively flexible manner, this would give an opportunity to the host State to easily escape its international obligations of investment protection, causing the balance in sustaining the necessity-induced detriment to shift so as to place relatively more financial burden on foreign investors than on other persons in the host State, creating yet again an unfair and undesirable situation.

Finally, as far as the "preclusive" set of requirements (Art. 25(2) ARSIWA) is concerned, it seems justified to seek for a substantial and not just any contribution of the host State to necessity. Bearing in mind the nature of situations in which necessity is likely to be invoked in international investment law (ecological and economic crises), it would seem appropriate to examine the (non-)substantial character of contribution by relying on objective, perhaps even scientific concepts, by analogy to the method of establishing graveness and imminence of peril.

\section{REFERENCES}

Agirrezabalaga, I. I., "El estado de necessidad, como causal eximente de la responsabilidadpordaños a las inversiones", Revista de Arbitraje Comercial y de Inversiones 1/2009.

Agius, M., "The Invocation of Necessity in International Law", Netherlands International Law Review 2/2009.

Ago, R., "Addendum to the Eighth Report on State Responsibility - Document A/CN.4/318/ADD.5-7", Yearbook of the International Law Commission vol. II(1), 1980.

Bishop, R. D., Crawford, J., Reisman W. M., Foreign Investment Disputes: Cases, Materials and Commentary, Kluwer Law International $2014^{2}$.

Bjorklund, A. K., "Emergency Exceptions: State of Necessity and Force Majeure", The Oxford Handbook of International Investment Law (eds. Peter Muchlinski, Federico Ortino, ChristophSchreuer), Oxford University Press, Oxford 2008.

Boed, R., "State of Necessity as a Justification for Internationally Wrongful Conduct", Yale Human Rights and Development Journal $1 / 2000$. 
Brownlie, I., Principles of Public International Law, Oxford University Press, Oxford $2008^{7}$.

Burke-White, W., von Staden Andreas, "Investment Protection in Extraordinary Times: The Interpretation and Application of Non-Precluded Measures Provisions in Bilateral Investment Treaties", Virginia Journal of International Law 2/2008.

Caron, D., "The ILC Articles on State Responsibility: The Paradoxical Relationship between Form and Authority", American Journal of International Law 4/2002.

Crawford, J., "Second Report on State Responsibility - Document A/ CN.4/498/ADD.1-4", 1999.

Dolzer, R., Schreuer, C., Principles of International Investment Law, Oxford University Press, Oxford $2012^{2}$.

Dumberry, P., "A Few Observations on the Remaining Fundamental Importance of Customary Rules in the Age of Treatification of International Investment Law", ASA Bulletin 1/2016.

Echandi, R., "Bilateral Investment Treaties and Investment Provisions in Regional Trade Agreements: Recent Developments in Investment Rulemaking", Arbitration under International Investment Agreements: A Guide to Key Issues (ed. Katia Yannaca-Small), Oxford University Press, Oxford 2010.

Fouret, J., "CMS c/ LG\&E ou l'état de nécessité en question", Revue de l'Arbitrage 2/2007.

Gazzini, T., "Foreign Investment and Measures Adopted on Ground of Necessity: Towards a Common Understanding", Transnational Dispute Management 1/2010

Heathcote, S., "Circumstances Precluding Wrongfulness in the ILC Articles on State Responsibility: Necessity", The Law of International Responsibility (eds. James Crawford, Alain Pellet, Simon Olleson), Oxford University Press, Oxford 2010

International Law Commission, "Report on State Responsibility - Document A/35/10", Yearbook of the International Law Commission vol. II(2), 1980.

International Law Commission, "Draft Articles on Responsibility of States for Internationally Wrongful Acts, with Commentaries" (hereinafter: Commentary), Yearbook of International Law Commission vol. II, 2001.

Martinez, A., "Invoking State Defenses in Investment Treaty Arbitration", The Backlash Against Investment Arbitration (eds. Michael Waibelet al.), Kluwer Law International 2010. 
Muchlinski, P., "Policy Issues", The Oxford Handbook of International Investment Law (eds. Peter Muchlinski, Federico Ortino, ChristophSchreuer), Oxford University Press, Oxford 2008.

Reinisch, A., "Necessity in Investment Arbitration", Netherlands Yearbook of International Law, vol. 40, 2010

Shaw, M., International Law, Cambridge University Press, Cambridge $2008^{6}$.

Sloane, R., "On the Use and Abuse of Necessity in the Law of State Responsibility", The American Journal of International Law 4/2012.

Sykes A., "Economic 'Necessity' in International Law", American Journal of International Law 2/2015.

Tomka, P., "Defenses Based on Necessity Under Customary International Law and on Emergency Clauses in Bilateral Investment Treaties", Building International Investment Law: The First 50 Years of ICSID (eds. Meg Kinnear et al.), Kluwer Law International 2015.

Vandevelde, K. J., "A Brief History of International Investment Agreements", University of California Davis Journal of International Law and Policy 1/2005.

Waibel, M., "Two Worlds of Necessity in ICSID Arbitration: CMS and LG\&E”, Leiden Journal of International Law 3/2007.

Article history: Received: 23. 10. 2016. Accepted: 28. 11. 2016. 